\title{
Environmental impact of coal based power plant of Rampal on the Sundarbans (world largest mangrove forest) and surrounding areas
}

\begin{abstract}
The physico-chemical conditions of air, water and soil, and biological conditions of the proposed Coal based Power Plant area (Rampal), Mongla and the Sundrabans were studied from August 2011 to July 2013 to assess the possible environmental impact on the Sundarbans and surrounding areas. Environmental Impact Assessment (EIA) of physical, biological, social and economic environment of the study areas indicate that most of the impacts of coal-fired power plant are negative and irreversible (-81) which can't be mitigated in any way. It is indicating that climate, topography, land use pattern, air and water quality, floral and faunal diversity, aquatic ecosystems, capture fisheries and tourism of the Sundarbans and the surroundings areas would be affected permanently due to proposed coal fired power plant. Increasing of water logging conditions, river erosion, noise pollution and health hazards; decreasing of ground water table; loss of culture fisheries, social forestry and major destruction of agriculture would be happened due to coal fired power plant. The benefits of proposed coal fired power plant of Rampal is very poor $(\mathrm{S}+19)$ than that of negative irreversible impact $(-81)$. So the proposed area is not suitable to establish the coal based power plant as the Sundarbans and surrounding areas would be affected permanently by establishing the proposed coal power plant.
\end{abstract}

Keywords: coal, power plant, rampal, the sundarbans, environmental impact
Volume 2 Issue 3 - 2017

\author{
Abdullah Harun Chowdhury \\ Environmental Science Discipline, Khulna University, Bangladesh
}

Correspondence: Abdullah Harun Chowdhury, Environmental Science Discipline, Khulna University, Bangladesh,

Email aharunc_ku@yahoo.com

Received: February 26, 2016 | Published: May II, 2017

\section{Introduction}

Coal based power plant produce electricity by burning coal in a boiler to heat water to produce steam. The steam, at tremendous pressure, flows into a turbine, which spins a generator to produce electricity. A typical 500-megawatt coal power plant creates more than 125,000 tons of ash and 193,000 tons of sludge each year which contain arsenic, mercury, chromium, and cadmium etc. and more than $75 \%$ of this waste is disposed of in unlined, unmonitored onsite landfills and surface impoundments as a result source of drinking water (ground water) is being contaminated and damage vital human organs and the nervous system. ${ }^{1}$ According to the studies of Billings ${ }^{1-3}$ ecosystems have been damaged sometimes severely or by the disposal of coal plant waste and heat. A coal power plant uses only $33-35 \%$ of the coal's heat to produce electricity and rest of the heat is released into the atmosphere and absorbed by the cooling water. ${ }^{4}$ Once the 2.2 billion gallons of water have cycled through the coal-fired power plant, they are released back into the lakes, rivers, or oceans with chlorine or other toxic chemicals which water is hotter (by up to $20-25^{\circ} \mathrm{F}$ ) than the natural water that receives it and this "thermal pollution" can decrease fertility and increase heart rates in fish.

According to, ${ }^{2}$ burning coal is a leading cause of smog, acid rain, global warming, and air toxics. Bangladesh government has decided to establish $1320 \mathrm{MW}$ coal-fired power plant at the mouth of the Sundarbans under Rampal upazila of Bagerhat district beside the Poshur river. The Bangladesh government signed a joint venture agreement with India's state-run electricity generation company (National Thermal Power Company) on 29 January 2012 to implement this project. By implementing this coal-fired power plant the Sundarbans will be affected as the sundarbans situated only $9 \mathrm{~km}$ downstream from the project site. ${ }^{5,6}$ The Sundarbans- the largest single tract mangrove forest has been declared Ramsar Site and Natural World Heritage which is situated in the South-West area $\left(21^{\circ} 31^{\prime}-22^{\circ} 38^{\prime} \mathrm{N}\right.$ and $89^{\circ} 00^{\prime}-89^{\circ} 55^{\prime} \mathrm{E}$ ) of Bangladesh. It is intersected by a network of tidal canals, creeks and rivers. It is covered an area of $6000 \mathrm{~km}^{2}$ of which $3956 \mathrm{~km}^{2}$ mangrove forest lands and more than $1800 \mathrm{~km}^{2}$ water bodies. ${ }^{7}$ This tidal forest is very rich with natural resources especially floral and faunal diversity like 66 species of plants, more than 200 fish species, 42 mammals, 234 birds, 51 reptiles, 8 amphibians, a lot of invertebrates etc. ${ }^{89}$ More than 500 thousand peoples are directly and indirectly depending on the Sundarbans for their livelihoods as well as socio-economic purposes. Around 200 thousand people go to the Sundarbans regularly to collect the resources for their livelihoods; less than 200 thousand collect the resources seasonally and around 100 thousand people are doing business of the collected resources and they never go to the Sundarbans directly for resources extraction; roughly $22 \%$ people's livelihoods are involved with the collection of wood resources; $5 \%$ are involved with the non-timber forest product; $69 \%$ are involved with the aquatic resources and $4 \%$ are involved with other purposes. ${ }^{10,11}$

Government has acquired 1,834 acres of agriculture land in Satmari-Katakhali and Koigordashkathi areas under Rampal upazila to establish the power plant. Only 86 acres lands are kash land and rest of the lands are public lands which were used for rice and fish cultivations by the land owners. The government has also taken an initiative for dredging 10 kilometers of the Poshur river to allow easy access of ships carrying coal for the plant. ${ }^{8,12}$ Due to an inadequate supply of local coal, the operator suggests to use imported coal. The Bangladesh 
government has decided to bring coal inside the Sundarbans through the Mongla sea port. Indian National Thermal Power Company and Bangladesh Power Development Board are the two signatories of the project. The proposed power plant will burn around 4.75 million tonnes of coal annually when more or less 0.71 million tonnes ashes and around 0.5 million tonnes sludge and liquid waste may be produced (CEGIS 2013). It would also emit a good amount of carbon dioxide $\left(\mathrm{CO}_{2}\right)$-key factor for global warming - some other toxic gases and airborne particles, according to Union of Concerned Scientists, a USA-based group. ${ }^{5,12}$ Discussed on the types and levels of pollution of coal-fired power plant. The ground water and water of the Poshur river may be polluted by the huge amount of waste produced due to burning of the coal. Whereas the existence of strict laws to protect the environment and the wildlife, the government has recently decided to declare a part of the Poshur and Andharmanik rivers sanctuaries for dolphins (Sankar 2012). Due to the Ecologically Critical Area (ECA) rules no power plant should be set up within $12 \mathrm{~km}$ of the Sundarbans buffer zone. ${ }^{13}$ The proposed project is $4 \mathrm{~km}$ away from the buffer zone of the Sundarbans. According to Ministry of Environment and Forests (2010) of India, any thermal power plant can't be established within $25 \mathrm{~km}$ from any natural forest or wild life habitats. But no such data or information on the possible environmental impact of proposed coal based power plant on the Sundarbans and Rampal areas are available. Under the circumstances, it has become imperative to institute an investigation on the estimation of coal-fired power plant hazards and their impacts on the floral and faunal communities of the Sundarbans and surroundings of the project area. The present study deals on the possible impact of coal-fired power plant of Rampal on the ecological and biological conditions of the Sudarbans and surroundings areas of the power plant. The findings of the study will help scientifically to assess the suitability of the coal based power plant in the proposed site.

\section{Materials and methods}

The research was studied from August 2011 to July 2013 in 10 permanent stations of each study area (Rampal, Mongla and the Sundarbans). Monthly sampling was carried out and air, water, soil and biological samples were studied in the field and laboratory. Secondary data were collected from published documents and different government offices. All data were analyzed and potential environmental impacts were indentified and calculated by using standard tools and methodologies. ${ }^{14}$ The samples of the river Pashur and Maidara were collected by using a country boat. Water samples were collected from $10-25 \mathrm{~cm}$ depth by using a scale ${ }^{15}$ for physicochemical analysis. A standard Secchi disc was used to measure the transparency of water while for water temperature a digital thermometer was used (Model No. 950). In situ measurements of total dissolved solids (TDS), conductivity, salinity, $\mathrm{pH}$, and dissolved oxygen (DO) were carried out with the help of respective portable field meters. Titrimetric methods were used to determine free $\mathrm{CO}_{2}$, $\mathrm{CO}_{3}$ and $\mathrm{HCO}_{3}$ alkalinities (Welch 1948). $\mathrm{BOD}, \mathrm{COD}, \mathrm{NO}_{3} \mathrm{~N}$ and other chemical parameters were measured following APHA (1989). Total hardness, calcium and magnesium were estimated following. ${ }^{16}$ Phosphate and silicate were measured following. ${ }^{17}$ Air and Noise Pollution have been measured by using instruments with the help of Environmental Science Discipline, Khulna University, Khulna. Emission rate of Suspended Particle Matter (SMP), $\mathrm{SO}_{\mathrm{x}}$ and $\mathrm{NO}_{\mathrm{x}}$ were measured by using High volume sampler (Envirotech APM415). Noise pollution was measured using Sound Level Meter (Lutorn, SL-4010). The sound level meter consists of microphone that converts the pattern of sound pressure fluctuations into an electrical voltage, amplifier and a voltage meter that is normally calibrated to read the decibel $(\mathrm{dB})$. Shovels and large ladders were used to collect the soil samples according to ${ }^{18}$ Soil quality was determined in the laboratory by following. ${ }^{19,20}$ The populations of aquatic and terrestrial plants in field were measured by following quadrat method (Ambasht 1974). Standard observations and monitoring methods ${ }^{21}$ (Foot/Pug marks per quadrat area/a standard area curve) were followed for different faunal study. Latitude and longitude were measured by using a hand GPS meter (model GARMIN GPSMAP ${ }^{\circledR} 78 \mathrm{~s}$ ). Statistical analysis among the different parameters was done by following. ${ }^{22}$

\section{Environmental impact assessment (EIA)}

Most of the development projects produce impacts on or changes in the state of natural environment. Of which some are positive and some are negative. Similarly, some positive and negative impacts have been identified for the Coal based Power Plant Project. The DOE (1997) guidelines for industries, ADB (2003) environmental assessment guidelines for initial environmental evaluation (IEE) and FPCO (1992) EIA guidelines were followed during impact assessment. Screening and scoping were used to determine the environmental issues and impacts for Coal fired Power Plant Project and identified as IECs. These issues and impacts had been evaluated in terms of distribution, quantity, quality, seasonality, ecological and socio-economic importance.

The sources of information for the scoping process were

i. Field visits and environmental survey;

ii. Collected data from KDA, Khulna University, DPHE, BWDB, Meteorological Department, Bangladesh Atomic Energy Center, Upazilas, UPs, NGOs etc.

iii. Meeting with chairmen, members, local people, govt. officials, teachers, social workers.

\section{Selection of important environmental components (IECs)}

Through the screening and scoping process (ADB 2003), the IECs relevant to environmental study of the proposed coal fired power plant project had been identified and presented in vertical column of Table 15. The IECs are climate, topography, land use, flood, river erosion, drainage congestion, surface water pollution, groundwater table depletion, groundwater pollution, loss of wetlands, air pollution, noise pollution, loss of habitats and biodiversity, loss of capture fisheries and agriculture, human population, literacy, status of women, water supply, sanitation, electricity and telephone facilities, health services, human diseases, solid waste, urbanization, industrialization, employment, business opportunity, housing, transportation, markets and bazaars, traffic congestion, fire hazard and tourism.

\section{Impact assessment matrix}

The impact assessment matrix is presented in Table 15 identified the potential impacts of coal based power plant of Rampal. The assessment matrix was done in consultation with multi-disciplinary team members. When an impact could not be quantified, qualitative judgment was used based on professional experience. The scoring was done within a 21 point score scale ranging from -1 to -10 for negative impacts and +1 to +10 for positive impacts while " 0 " was used for no impact (neutral impact) (Pastakia and Jensen 1998). 


\section{Results and discussion}

The physico-chemical conditions of air, water and soil of the proposed coal fired area (Rampal), Mongla and Sundrabans were studied and data are presented in Tables 1-6. The biological components of the study area had also been studied (Tables 7-14) which are presented in the following pages. Wind direction for the last ten years of the study areas was north to south or north-west to south-east facing from the month of November to February in every year. In the study areas monthly average air temperature varied from 13.5 to $35^{\circ} \mathrm{C}$; relative humidity and rainfall varied from 65 to $86 \%$ and 7 to $320 \mathrm{~mm}$; SPM, NOx and SOx varied from 145 to $312 \mathrm{mg} /$ $\mathrm{m}^{3}, 12$ to $109 \mu \mathrm{g} / \mathrm{m}^{3}$ and 9 to $61 \mu \mathrm{g} / \mathrm{m}^{3}$ respectively. Surface water temperature, TDS, conductivity, salinity, $\mathrm{pH}, \mathrm{DO}, \mathrm{BOD}_{5}, \mathrm{COD}$, total hardness and $\mathrm{PO}_{4}$ varied from 22 to $35.5^{\circ} \mathrm{C}, 3$ to $23 \mathrm{~g} / 1,4$ to $16.6 \mathrm{~ms} /$ $\mathrm{cm}, 2$ to $22 \mathrm{ppt}, 7.1$ to $8.9,6.1$ to $8.1 \mathrm{mg} / 1,1.3$ to $2.4 \mathrm{mg} / 1,3.5$ to $9.1 \mathrm{mg} / 1,660$ to $1210 \mathrm{mg} / 1$ and 1.53 to $2.55 \mathrm{mg} / 1$ respectively. Ground water arsenic varied from 0.01 to $0.21 \mathrm{mg} / 1$. Soil $\mathrm{pH}$, Sulpher and Iron were recorded from 7.3 to $8.1,44.5$ to $1031 \mathrm{micro-gram} / \mathrm{g}$ soil and 16 to 108 micro-gram/g soil respectively. During the period of study total 24 herbs, grasses and shrubs were recorded and among them 8 were rare in the project area and 2 were also rare outside of the project area. A total 47 natural woody plants and fruit trees were recorded and among them 5 were in extinct condition, 15 natural woody and fruit trees, and 8 natural woody and fruit trees were recorded as rare in the project and outside the project area respectively. Out of 36 medicinal plants and non-fruit trees 8 species were in extinct condition and 20 were recorded as rare in the project area; 14 medicinal plants and nonfruit trees were also recorded as rare outside of the project area. 6 aquatic macrophytes were recorded as rare out of 14 species. A total 59 species of shrimp, crab, mollusks and fishes were recorded but 18 fishes were extinct and 10 fishes were rare in the project area. 7 species of shrimp, crab and mollusks were also rare in the project area. During the period of study only 3 amphibians were recorded in the project area but 2 were rare. 11 reptiles were recorded in the project area but 2 were extinct and 4 were rare species. In the period of study 24 terrestrial and 10 wetlands birds were recorded but among them 7 rare and 3 extinct terrestrial birds, and 6 extinct and 2 rare wetlands birds were recorded. Only 11 mammals were recorded during the period of study but most of them were extinct in the project area and those were also threatened outside of the project area.

On the basis of present conditions of the study areas like physicochemical conditions of air, water and soil; meteorological data (Tables 1-6) and, floral and faunal status (Tables 7-14) it can be concluded that inside and outside of the project area such as Rampal, Mongla and the adjacent Sundarbans are free from different types of pollution except salinity intrusion. More or less similar observations were also made by ${ }^{22-25}$ recorded dolphins, crocodile, Maskedfinfoot, migratory birds, wild boar, deer, snakes, fishes, different mammals etc. inside the Sundarbans, in and around the rivers and their connected canals and creeks of the Sundarbans. Floral and faunal statuses (Table 7-14) are indicating that some plants and animals are already in extinct conditions and some are in rare conditions due to natural climatic hazards. Due to pollution of the coal fired power plant rest of the floral and faunal diversity will be destroyed by changing air, water and soil quality of the study areas. According to EIA study of CEGIS (2013) the proposed coal based power plant will discharge 51830 Metric Tons (MT) Sulfur di-oxide $\left(\mathrm{SO}_{\mathrm{x}}\right)$ yearly and $17277 \mathrm{MT} \mathrm{SO}_{\mathrm{x}}$ during dry season (16 November to 15 March) if power plant burn less sulfur content $(<0.6 \%)$ coal; emission of Nitrigen di-oxide $\left(\mathrm{NO}_{\mathrm{x}}\right)$ will be 31025 MT yearly and 10342 MT during dry season; 711750 MT ash will produce yearly and 237250 MT will produce during dry seasons; yearly 23783184060 gallons and during dry season 7927728020 gallons water will intake by this power plant from the Pashur river; yearly 10397020354 gallons water will be consumed and 13386163706 gallons cooling/ waste water will be discharged to the Pashur river directly or indirectly and ultimately polluted water flows to the Sunderbans as the Pashur meets the sea by flowing inside the Sundarbans. CEGIS (2013) also mentioned that after starting the Rampal coal based power plant the $\mathrm{SO}_{\mathrm{x}}$ level will be reached $50.4-53.4 \mathrm{ig} / \mathrm{m}^{3}$ and $\mathrm{NO}_{\mathrm{x}}$ level will be reached $47.2-51.2 \mathrm{ig} / \mathrm{m}^{3}$ inside the Sundarbans if use best quality coal; whereas present $\mathrm{SO}_{\mathrm{x}}$ level is $8-11 \mathrm{ig} / \mathrm{m}^{3}$ and $\mathrm{NO}_{\mathrm{x}}$ level is $16-20 \mathrm{ig} / \mathrm{m}^{3}$ inside the Sundarbans. Last ten years wind flows directions (Table 1) and CEGIS (2013) produced wind flows diagram indicate that during dry season (from 16 November to 15 March) the Sundarbans will receive directly $\mathrm{SO}_{\mathrm{X}}, \mathrm{NO}_{\mathrm{x}}$ and other gases from the power plant. As a result floral and faunal diversity of the Sundarbans will be affected gradually day by day and endangered species will be injured seriously in aquatic and forest floors as during dry season there is no possibility of dilute of gases by rainfall. Dispersion models of different gases of CEGIS (2013) indicate that $\mathrm{SO}_{\mathrm{x}}, \mathrm{NO}_{\mathrm{x}}$ and other gases will flows up to $35 \mathrm{~km}$ inside the Sundarbans during dry season in every year. Surrounding agricultural (rice, shrimp etc.) lands and wetlands (the river Pashur, Maidara and other tidal canals) of the coal power plants will be affected by the leaching of toxic substances from deposited coal burned ashes; the ashes contain many heavy metals including arsenic, lead, mercury, nickel, vanadium, beryllium, barium, cadmium, chromium, selenium and radium, which are dangerous if released into environment (CEGIS 2013). These heavy metals can change the soil and water quality of the Sundarbans by mixing runoff rain water during rainy reason. ${ }^{12}$ described on the emission level of different toxic gases and heavy metals of coal fired power plant. Human health hazards and possible impact on the Sundarbans due to coal-fired power plant have also been discussed by. ${ }^{5}$ The wind flow is indicating that the total study area i.e. Rampal, Mongla and the Sundarbans will be affected by the toxic gases and ashes of the coal based power plant in different seasons. Especially the Sundarbans will be affected during pick tourism period in the month of December to February. It is a matter to be concerned when the Sundarbans reserve forest is already facing threats from natural calamity, deforestation, rise in salinity and extinction of many species mainly due to human carelessness, ignorance and lack of implementation of laws, poaching and illegal wildlife trade. ${ }^{26,27}$ Study of ${ }^{28-30}$ on the impacts of oil spill on the Sundarbans indicates that sink of coal loaded ship created some problems for the biodiversity and ecological conditions of the Sundarbans.

Environmental Impact Assessment (EIA) ${ }^{31-35}$ of physical, biological, social and economic environment of the Sundarbans and the surrounding areas indicate that most of the impacts of coalfired power plant are negative and irreversible (-81) which can't be mitigated in any way. It is indicating that climate, topography, land use pattern, air and water (surface and ground both) quality, floral and faunal diversity, aquatic ecosystems, capture fisheries and tourism of the Sundarbans and the surrounding areas will be affected permanently due to proposed coal fired power plant. Increasing of water logging conditions, river erosion, noise pollution and health hazards; decreasing of ground water table; loss of culture fisheries, social forestry and health hazards, and major destruction of agriculture will be happened due to coal fired power plant. These 
problems may be reversible after long mitigation process excep agriculture. But all reversible mitigations are negative (total no. is $-67) \cdot{ }^{36-38}$ Mitigation of agricultural loss will be very difficult and many people will become land less. Urbanization, development of markets/ bazaars, transportation and industrialization will be developed which may be sustainable but mitigation must be ensured. The total no. of sustainable mitigation is only +14 which indicate that the study area is not suitable for industrialization and urbanization (Table 15). By establishing the coal fired power plant only electrification in the rural area, and very few job and localized business facilities will be increased. The benefits/facilities of proposed coal fired power plant of Rampal is very poor $(\mathrm{S}+19)$ than that of negative irreversible impact
(-81). So environmentally, physically, socially and economically the selected area is not suitable to establish any type of coal based power plant. On the basis of IECs and EIA, coal based power plant will be act as "to add insult to injure" in the project area as well as on the Sundarbans, Rampal and Mongla areas. A long term research and intensive monitoring must be done to find out the detail information on the long term impact of coal based power plant on the biodiversity and ecological conditions of the Sundarbans before introducing the coal based power plant in Rampal. Otherwise the fragile ecosystem of the Sundarbans including its buffer zone could be threatened by the pollutants of the coal based power plant of Rampal.

Table I Monthly prevailing winds speed in knots and direction of the study areas from 2003-20I2

\begin{tabular}{|c|c|c|c|c|c|c|c|c|c|c|c|c|c|c|c|c|c|c|c|c|c|c|c|}
\hline \multirow{2}{*}{ Year } & \multirow{2}{*}{$\frac{\text { Jan. }}{\text { Spd Dir }}$} & \multicolumn{2}{|c|}{ Feb. } & \multicolumn{2}{|c|}{ Mar. } & \multicolumn{2}{|c|}{ Apr. } & \multicolumn{2}{|c|}{ May. } & \multicolumn{2}{|c|}{ Jun. } & \multicolumn{2}{|c|}{ Jul. } & \multicolumn{2}{|c|}{ Aug. } & \multicolumn{2}{|c|}{ Sep. } & \multicolumn{2}{|c|}{ Oct. } & \multicolumn{2}{|c|}{ Nov. } & \multicolumn{2}{|c|}{ Dec. } \\
\hline & & Spd & Dir & Spd & Dir & $\mathrm{S}_{1}$ & Dir & Spd & Dir & $\mathrm{Spc}$ & Dir & Spd & Dir & Spd & Dir & Spd & Dir & Spd & Dir & Spd & Dir & Spd & Dir \\
\hline 003 & $3.4 \mathrm{~N}$ & 2.9 & NW & 3.8 & NW & 4.7 & $\mathrm{~S}$ & 5.2 & $\mathrm{~S}$ & 4.8 & $\mathrm{~S}$ & 4.0 & $\mathrm{~s}$ & 3.8 & $\mathrm{~S}$ & 3.4 & $\mathrm{~s}$ & 3.0 & $\mathrm{~S}$ & 2.6 & $\mathbf{N}$ & 2.3 & NW \\
\hline 004 & $3.3 \mathrm{NW}$ & 3.3 & NW & 3.4 & $\mathrm{~s}$ & 40 & $\mathrm{~s}$ & 4.8 & $\mathrm{~s}$ & 3.4 & $\mathrm{~s}$ & 3.3 & $\mathrm{~s}$ & 3.3 & $\mathrm{~S}$ & 4.1 & SE & 3.6 & E & 2.1 & NW & 2.5 & NW \\
\hline 05 & $2.9 \mathrm{NW}$ & 3.0 & $\mathrm{~N}$ & 4. & 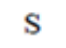 & 4.0 & 3 & 4.1 & $\mathrm{~S}$ & 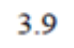 & S & 3.6 & $\mathrm{~s}$ & 3.2 & $\mathrm{~S}$ & 3.0 & $\mathrm{~S}$ & 2.4 & $\mathrm{~S}$ & 2.1 & NW & 2.3 & NW \\
\hline 06 & $2.8 \mathrm{NW}$ & 2.8 & NW & 3.0 & $\mathrm{~s}$ & 5.0 & $\mathrm{~s}$ & 3.9 & $\mathrm{~S}$ & 3.0 & 3 & 3.4 & $\mathrm{~s}$ & 2.9 & $\mathrm{~s}$ & 2.8 & $\mathrm{~S}$ & 2.4 & $\mathrm{~s}$ & 2.3 & $\mathrm{~N}$ & 2.5 & $\mathrm{~N}$ \\
\hline 2007 & $2.7 \mathrm{~N}$ & 3.6 & $\mathrm{~N}$ & 3.9 & S & 4.8 & 3 & 4.4 & S & 3.2 & 3 & 3.0 & $\mathrm{~s}$ & 3.0 & $\mathrm{~S}$ & 2.6 & $\mathrm{~S}$ & 2.7 & $\mathrm{~N}$ & 2.5 & $\mathrm{~N}$ & 2.4 & $\mathrm{~N}$ \\
\hline 2008 & $3.1 \mathrm{~N}$ & 3.3 & NW & 3.6 & $\mathrm{~S}$ & 4.8 & $\mathrm{~S}$ & 4.0 & $\mathrm{~S}$ & 4.1 & $\mathrm{~S}$ & 3.5 & $\mathrm{~S}$ & 3.0 & $\mathrm{~S}$ & 2.6 & $\mathrm{~S}$ & 3.4 & E & 2.2 & NW & 2.9 & $\mathrm{~N}$ \\
\hline 2009 & $3.6 \mathrm{~N}$ & 2.9 & NW & 3.9 & $\mathrm{~S}$ & 5.3 & $\mathrm{~S}$ & 3.2 & $\mathrm{~S}$ & 2.8 & $\mathrm{~S}$ & 3.3 & $\mathrm{~S}$ & 4.0 & SE & 3.7 & $\mathrm{~S}$ & 2.3 & NW & 2.2 & NW & 2.4 & $\mathrm{~N}$ \\
\hline 2010 & $2.8 \mathrm{~N}$ & 2.7 & $\mathrm{~s}$ & 2.8 & 5 & 2.9 & 3 & 3.2 & $\mathrm{~S}$ & 3.5 & 3 & 3.3 & $\mathrm{~S}$ & 2.7 & $\mathrm{~s}$ & 4.3 & SE & 3.0 & 3 & 2.3 & NW & 2.4 & NNW \\
\hline 2011 & $2.6 \mathrm{~N}$ & 2.6 & $\mathrm{~s}$ & 2.1 & SW & 2.8 & $\mathrm{~S}$ & 3.7 & $\mathrm{~s}$ & 3.9 & $\mathrm{~S}$ & 2.9 & $\mathrm{~S}$ & 2.9 & $\mathrm{~s}$ & 4.4 & $\mathrm{~S}$ & 2.8 & $\mathrm{~s}$ & 4.0 & $\mathrm{~N}$ & 3.2 & $\mathrm{~N}$ \\
\hline 2012 & $2.8 \mathrm{~N}$ & 3.4 & $\mathrm{~s}$ & 3.2 & $\mathrm{~s}$ & 3.5 & $\mathrm{~s}$ & 3.0 & $\mathrm{~s}$ & 3.1 & $\mathrm{~s}$ & 3.3 & $\mathrm{~S}$ & 2.9 & $\mathrm{~s}$ & 3.4 & $\mathrm{~S}$ & 2.4 & W & 2.5 & $\mathrm{~N}$ & 2.3 & $\mathrm{~N}$ \\
\hline
\end{tabular}

Source: Bangladesh metrological department, 2013

Table 2 Climatic conditions of the study areas (10 years average)

\begin{tabular}{|c|c|c|c|c|c|c|c|c|c|c|c|c|}
\hline \multirow{2}{*}{ Parameters } & \multicolumn{12}{|c|}{ Month } \\
\hline & Jan & Feb & Mar & Apr & May & June & July & Aug & Sept & Oct & Nov & Dec \\
\hline Temp. Avg. Max. $\left({ }^{\circ} \mathrm{C}\right)$ & 25.1 & 30 & 32.6 & 34.9 & 35 & 34.9 & 32.8 & 32.7 & 31.9 & 31.9 & 29.8 & 26.4 \\
\hline Temp. Avg. Min. $\left({ }^{\circ} \mathrm{C}\right)$ & 13.5 & 17.3 & 22.1 & 25.2 & 25.9 & 27.3 & 27.1 & 25.6 & 23.8 & 23.8 & 18.5 & 14.5 \\
\hline Temp. Mean $\left({ }^{\circ} \mathrm{C}\right)$ & 17.2 & 20.4 & 25.2 & 29.3 & 29.8 & 29.8 & 29.3 & 29.4 & 28.9 & 27.4 & 23.7 & 19.2 \\
\hline Relative Humidity Mean (\%) & 69 & 65 & 72 & 76 & 79 & 86 & 83 & 81 & 79 & 77 & 72 & 70 \\
\hline Rainfall Mean (mm) & 7 & 10 & 148 & 47 & 215 & 103 & 314 & 246 & 320 & 110 & 18 & 9 \\
\hline Sunshine Hour (hr) & 6.9 & 8 & 8.3 & 8.3 & 7.2 & 5.5 & 4.5 & 4.8 & 5.3 & 7.2 & 7.9 & 7.6 \\
\hline Wind Speed Avg.(Nautical miles/hr) & 7.6 & 10.7 & 9.7 & 13 & 14.2 & 12.7 & 12.5 & 9.6 & 11.6 & 7.9 & 7 & 6.7 \\
\hline
\end{tabular}

Source: Khulna meteorological office, 2013

Table 3 Air quality of study areas

\begin{tabular}{lllllll}
\hline \multirow{2}{*}{ Study location } & $\mathbf{S P M}\left(\mathbf{m g} / \mathbf{m}^{3}\right)$ & & $\mathbf{N O}_{\mathbf{x}}\left(\boldsymbol{\mu g} / \mathbf{m}^{3}\right)$ & \multicolumn{3}{c}{$\mathbf{S O}_{\mathbf{x}}\left(\boldsymbol{\mu g} / \mathbf{m}^{3}\right)$} \\
\cline { 2 - 7 } & Working day & Holiday & Working day & Holiday & Working day & Holiday \\
\hline Rampal area & $172-292$ & 268 & $53-85$ & 72 & $37-52$ & 45 \\
Mongla area & $183-312$ & 314 & $65-109$ & 98 & $45-61$ & 52 \\
Sundarbans area & $145-179$ & & $21-\mathrm{Dec}$ & & $15-\mathrm{Sep}$ & - \\
EQS- Bangladesh & 400 & - & 80 & - & 80 & -
\end{tabular}

Source: Field study, 20II-20I3 
Table 4 Physico-chemical conditions of water of the study areas

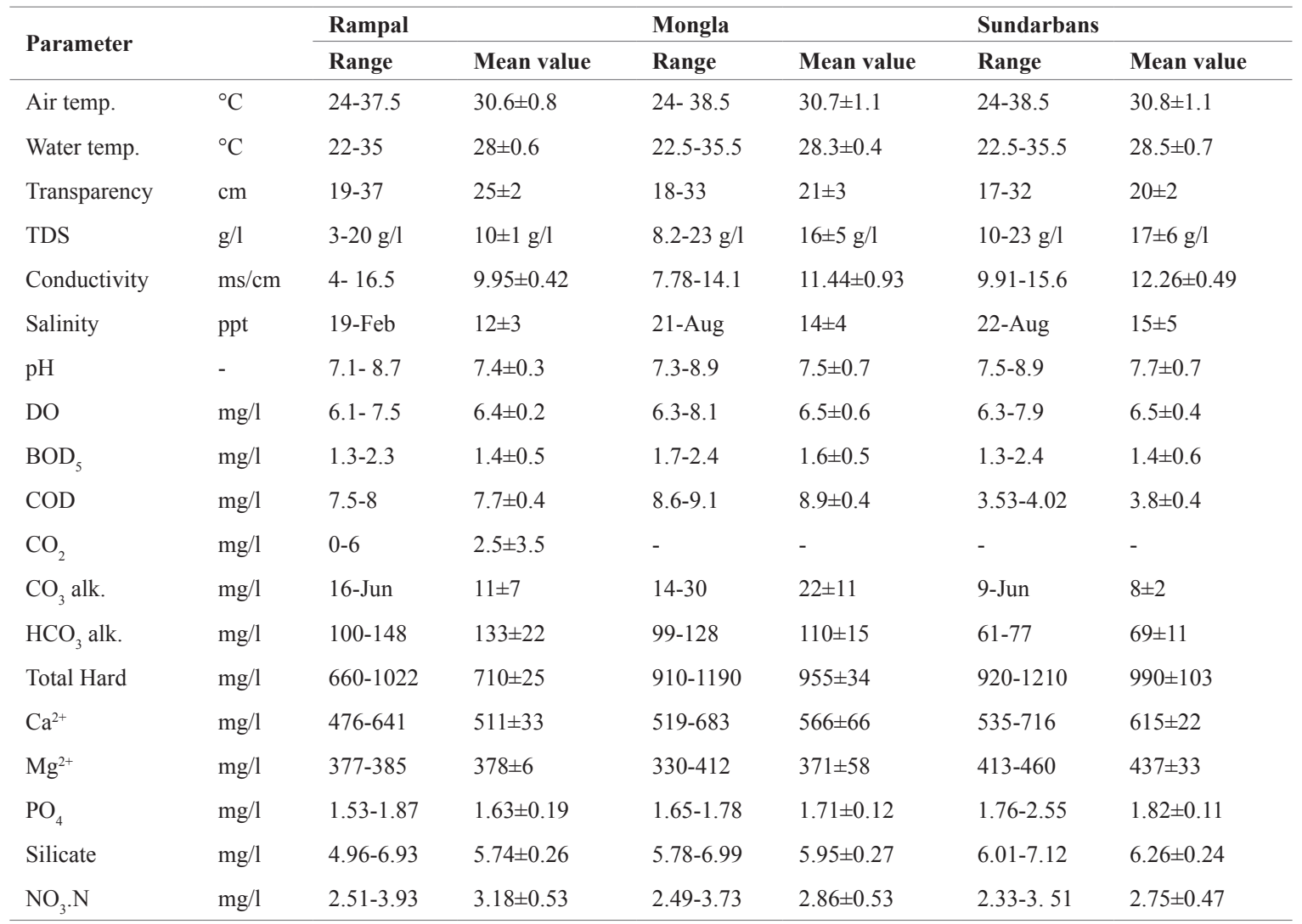

\section{- = Not detected}

Table 5 Physico-chemical conditions of groundwater of the study areas

\begin{tabular}{|c|c|c|c|c|}
\hline \multirow{2}{*}{ Parameter } & \multirow{2}{*}{ Units } & \multicolumn{3}{|l|}{ Value } \\
\hline & & Rampal & Mongla & Sundarbans \\
\hline Depth & $\mathrm{m}$ & $60-125$ & $75-140$ & $75-140$ \\
\hline $\mathrm{pH}$ & - & $7.5-7.9$ & $7.4-8.1$ & $7.5-8.2$ \\
\hline TDS & $\mathrm{mg} / 1$ & $454-1660$ & $617-2584$ & $635-2610$ \\
\hline E. Conductivity & $\mu \mathrm{s} / \mathrm{cm}$ & $908-3270$ & $1170-3654$ & $1126-3709$ \\
\hline Salinity & $\mathrm{ppt}$ & $00-13$ & 16-May & 16-May \\
\hline Arsenic & $\mathrm{mg} / 1$ & $0.01-0.21$ & $0.01-0.17$ & $0.01-0.12$ \\
\hline Total Iron & $\mathrm{mg} / 1$ & $0.16-2.89$ & $0.34-3.24$ & $0.18-3.29$ \\
\hline $\mathrm{HCO}_{3}$ & $\mathrm{mg} / 1$ & $315-651$ & $244-632$ & $229-645$ \\
\hline $\mathrm{Ca}^{+}$ & $\mathrm{mg} / \mathrm{l}$ & $39-122$ & $37-151$ & $29-154$ \\
\hline $\mathrm{Mg}^{+}$ & $\mathrm{mg} / 1$ & $15-63$ & $22-82$ & $23-89$ \\
\hline $\mathrm{Na}^{+}$ & $\mathrm{mg} / 1$ & $135-514$ & $154-642$ & $164-657$ \\
\hline Uranium & $\mathrm{Ppb}$ & $4.46-11.58$ & - & - \\
\hline
\end{tabular}

Source: Field study $201 \mathrm{I}-2013$.

Citation: Chowdhury AH. Environmental impact of coal based power plant of Rampal on the Sundarbans (world largest mangrove forest) and surrounding areas. MOJ Eco Environ Sci. 2017;2(3):85-98. DOI: 10.15406/mojes.2017.02.00022 
Table 6 Chemical properties of the soils of the study areas

\begin{tabular}{|c|c|c|c|c|c|c|c|c|c|c|c|c|c|c|}
\hline \multicolumn{15}{|c|}{ Type of soil associations } \\
\hline \multirow{2}{*}{ Study area } & \multirow{2}{*}{ pH } & \multirow{2}{*}{$\begin{array}{l}\text { Salinity } \\
\text { ppt }\end{array}$} & \multirow{2}{*}{$\begin{array}{l}\text { Org. } \\
\text { Mat \% }\end{array}$} & \multirow{2}{*}{$\mathbf{N} \%$} & $\mathbf{P}$ & $\mathbf{S}$ & Zn & $\mathrm{Br}$ & $\mathbf{K}$ & $\mathrm{Ca}$ & Mg & $\mathbf{C u}$ & $\mathrm{Fe}$ & Mn \\
\hline & & & & & \multicolumn{4}{|c|}{ micro-gram/g soil } & \multicolumn{3}{|c|}{$\mathrm{mv} / 100 \mathrm{~g}$ soil } & \multicolumn{3}{|c|}{ micro-gram/g soil } \\
\hline Rampal & $\begin{array}{l}7.3- \\
8.1\end{array}$ & $2.3-7.8$ & $1.7-2.7$ & $\begin{array}{l}0.07- \\
0.15\end{array}$ & $\begin{array}{l}\text { Sep- } \\
60\end{array}$ & $170-476$ & $1.6-3.3$ & $0.76-$ & $\begin{array}{l}0.59- \\
0.85\end{array}$ & $8.3-3$ & $1-6.33$ & $\begin{array}{l}4.7- \\
9.3\end{array}$ & $\begin{array}{l}21- \\
108\end{array}$ & $\begin{array}{l}12- \\
46.6\end{array}$ \\
\hline Mongla & $\begin{array}{l}7.3- \\
8.1\end{array}$ & $5-8.5$ & $\begin{array}{l}1.63- \\
2.23\end{array}$ & $\begin{array}{l}0.07- \\
0.11\end{array}$ & $\begin{array}{l}4.2- \\
8.2\end{array}$ & $280-1031$ & $0.4-0.6$ & $\begin{array}{l}0.53- \\
1.55\end{array}$ & $\begin{array}{l}0.57- \\
1.24\end{array}$ & $\begin{array}{l}11- \\
21.5\end{array}$ & $\begin{array}{l}5.05- \\
9.75\end{array}$ & $\begin{array}{l}2.8- \\
6.2\end{array}$ & $\begin{array}{l}16- \\
66\end{array}$ & $\begin{array}{l}22- \\
\text { Apr }\end{array}$ \\
\hline Sundarbans & $\begin{array}{l}7.6- \\
8.1\end{array}$ & $3.0-19$ & $1.37-2.8$ & $\begin{array}{l}0.07- \\
0.15\end{array}$ & $\begin{array}{l}4.1- \\
7.5\end{array}$ & $44.5-387.3$ & $\begin{array}{l}0.56- \\
0.99\end{array}$ & $\begin{array}{l}0.56- \\
2.54\end{array}$ & $\begin{array}{l}0.27- \\
1.16\end{array}$ & $3-34.5$ & $5-12.5$ & $\begin{array}{l}3.91- \\
7.67\end{array}$ & $\begin{array}{l}20.5- \\
72\end{array}$ & $\begin{array}{l}10.6- \\
35\end{array}$ \\
\hline
\end{tabular}

Source: Field study 20I I-200 I3

Table 7 Herbs, grasses and shrubs of the study areas (except the Sundarbans)

\begin{tabular}{|c|c|c|c|}
\hline \multirow{2}{*}{ Local name } & \multirow{2}{*}{ Scientific name } & \multicolumn{2}{|l|}{ Status } \\
\hline & & Outside the project area & Project area \\
\hline Assamlata/Baraty & Eupatorium odoratum & $\mathrm{Vc}$ & $\mathrm{C}$ \\
\hline Bish-katali & Polygonum hydropiper & $\mathrm{C}$ & $\mathrm{R}$ \\
\hline Badaeya & Andropogon aciculatus & $\mathrm{C}$ & $\mathrm{F}$ \\
\hline Banna danga shak & Amaranthus viridis & $\mathrm{F}$ & $\mathrm{F}$ \\
\hline Bilai achra & Mucuna pruriens & $\mathrm{F}$ & $\mathrm{F}$ \\
\hline Dubba ghas & Cynodon dactylon & $\mathrm{Vc}$ & $\mathrm{C}$ \\
\hline Fenkachu/Mankachu & Alocasia indica & $\mathrm{F}$ & $\mathrm{R}$ \\
\hline Fanimonasha & Euphorbia neriifolia & $\mathrm{R}$ & $\mathrm{R}$ \\
\hline Gimashak & Glinus oppositifolius & $\mathrm{C}$ & $\mathrm{R}$ \\
\hline Kukurmuta & Blumea lacera & $\mathrm{C}$ & $\mathrm{F}$ \\
\hline Khuirakata/Kata danga & Amaranthus spinosus & $\mathrm{F}$ & $\mathrm{F}$ \\
\hline Kachu & Colocasia esculenta & $\mathrm{Vc}$ & $\mathrm{C}$ \\
\hline Kashjar & Saccharum spontaneum & $\mathrm{F}$ & $\mathrm{R}$ \\
\hline Lajjabati & Mimosa pudica & $\mathrm{R}$ & $\mathrm{R}$ \\
\hline Marich (Banna) & Croton bonplandianum & $\mathrm{C}$ & $\mathrm{F}$ \\
\hline Shealmotra & Vernonia patula & $\mathrm{F}$ & $\mathrm{F}$ \\
\hline Telakucha & Coccinea cordifolia & $\mathrm{C}$ & $\mathrm{F}$ \\
\hline \multicolumn{4}{|l|}{ Shrubs } \\
\hline Varanda/Venna & Ricinus communis & $\mathrm{F}$ & $\mathrm{R}$ \\
\hline Bhat & Clerodendrum viscosum & $\mathrm{C}$ & $\mathrm{F}$ \\
\hline Bet & Calamus sp. & $\mathrm{F}$ & $\mathrm{E}$ \\
\hline Dhaincha/Dhanchi & Sesbania cannabina & $\mathrm{F}$ & $\mathrm{R}$ \\
\hline Gagra & Xanthium strumarium & $\mathrm{C}$ & $\mathrm{F}$ \\
\hline Chitki & Phyllanthus reticulatus & $\mathrm{C}$ & $\mathrm{F}$ \\
\hline Titabegun & Solanum torvum & $\mathrm{F}$ & $\mathrm{F}$ \\
\hline
\end{tabular}

Status:VC, very common; C, common; F, fairly common; R, rare; E, endangered; T, threatened; Et, extinct (Source: Field study 20I I-20I3). 
Table 8 Natural woody plants and fruit trees of the study areas (except the Sundarbans)

\begin{tabular}{|c|c|c|c|}
\hline Local name & Scientific name & \multicolumn{2}{|l|}{ Status } \\
\hline \multicolumn{2}{|l|}{ Natural woody plants } & Outside the project area & Project area \\
\hline Bannay & Crataeva religiosa & $\mathrm{R}$ & Et \\
\hline Debdaru & Polyalthia longifolia & $\mathrm{R}$ & $\mathrm{R}$ \\
\hline Jobb dumur & Ficus racemosa & $\mathrm{F}$ & $\mathrm{R}$ \\
\hline Kharajura & Litsea monopetala & $\mathrm{F}$ & $\mathrm{R}$ \\
\hline Kadam & Anthocephalus chinensis & $\mathrm{F}$ & $\mathrm{R}$ \\
\hline $\mathrm{Gab}$ & Diospyros peregrine & $\mathrm{F}$ & Et \\
\hline Gudu/Pitadonga/Medda & Trewia nudiflora & $\mathrm{F}$ & $\mathrm{F}$ \\
\hline Khoksha/dumur & Ficus sp. & $\mathrm{C}$ & $\mathrm{F}$ \\
\hline Kharchuna/Teet gila & Derris indica & $\mathrm{R}$ & $\mathrm{R}$ \\
\hline Chattim/Chaitan & Alstonia scholaris & $\mathrm{R}$ & $\mathrm{R}$ \\
\hline Shaora & Streblus asper & $\mathrm{F}$ & $\mathrm{R}$ \\
\hline Titijam & Eugenia sp. & $\mathrm{F}$ & Et \\
\hline Iika & Alangium salvifolium & $\mathrm{F}$ & Et \\
\hline Pitraj & Amoora rohituka & $\mathrm{C}$ & $\mathrm{F}$ \\
\hline Jarul & Lagerstroemia speciosa & $\mathrm{F}$ & $\mathrm{R}$ \\
\hline Hijal & Barringtonia acutangula & $\mathrm{E}$ & Et \\
\hline Harhari/Shola & Trema orientalis & $\mathrm{F}$ & $\mathrm{F}$ \\
\hline Nim & Azadirachta indica & $\mathrm{F}$ & $\mathrm{R}$ \\
\hline Shimul & Salmalia malabarica & $\mathrm{F}$ & $\mathrm{R}$ \\
\hline \multicolumn{4}{|l|}{ Fruit trees } \\
\hline Aam & Mangifera indica & $\mathrm{Vc}$ & $\mathrm{C}$ \\
\hline Amloki & Phyllanthus emblica & $\mathrm{R}$ & $\mathrm{R}$ \\
\hline Amrah & Spondias pinnata & $\mathrm{F}$ & $\mathrm{F}$ \\
\hline Ata (Sharpha) & Annona squamosa & $\mathrm{F}$ & $\mathrm{F}$ \\
\hline Ata (Nuna) & Annona reticulata & $\mathrm{F}$ & $\mathrm{F}$ \\
\hline Bel & Aegle marmelos & $\mathrm{F}$ & $\mathrm{F}$ \\
\hline Boroi/Kul & Ziziphus jujuba & $\mathrm{C}$ & $\mathrm{F}$ \\
\hline Chalta & Dillenia indica & $\mathrm{R}$ & $\mathrm{R}$ \\
\hline Dalim & Punica granatum & $\mathrm{F}$ & $\mathrm{F}$ \\
\hline Deophal & Artocarpus lacucha & $\mathrm{R}$ & $\mathrm{E}$ \\
\hline Jam & Syzygium cumini & $\mathrm{C}$ & $\mathrm{F}$ \\
\hline Jambura & Citrus grandis & $\mathrm{F}$ & $\mathrm{R}$ \\
\hline Jamrul & Eugenia javanica & $\mathrm{F}$ & $\mathrm{F}$ \\
\hline Kala & Musa spp. & $\mathrm{C}$ & $\mathrm{F}$ \\
\hline Kamranga & Averrhoa carambola & $\mathrm{F}$ & $\mathrm{F}$ \\
\hline Karamcha & Carissa carandas & $\mathrm{R}$ & $\mathrm{R}$ \\
\hline Kadbel & Feronia elephantum & $\mathrm{C}$ & $\mathrm{C}$ \\
\hline Kanthal & Artocarpus heterophyllus & $\mathrm{C}$ & $\mathrm{F}$ \\
\hline Khejur & Phoenix sylvestris & $\mathrm{C}$ & $\mathrm{F}$ \\
\hline Lebu & Citrus spp. & $\mathrm{C}$ & $\mathrm{C}$ \\
\hline Narikel & Cocos nucifera & $\mathrm{C}$ & $\mathrm{C}$ \\
\hline Pepe & Carica papaya & $\mathrm{C}$ & $\mathrm{F}$ \\
\hline Peyara & Psidium guajava & $\mathrm{C}$ & $\mathrm{C}$ \\
\hline Sajna & Moringa oleifera & $\mathrm{C}$ & $\mathrm{F}$ \\
\hline Supari & Areca catechu & $\mathrm{C}$ & $\mathrm{C}$ \\
\hline Safeda & Achras zapota & $\mathrm{C}$ & $\mathrm{C}$ \\
\hline Tal & Borassus flabellifer & $\mathrm{C}$ & $\mathrm{F}$ \\
\hline Tetul & Tamarindus indica & $\mathrm{F}$ & $\mathrm{R}$ \\
\hline
\end{tabular}

Status:VC, very common; C, common; F, fairly common; R, rare; E, endangered; T, threatened; Et, extinct (Source: Field study 20II-2013) 
Table 9 Wild medicinal plants and non-fruit trees of the study areas (except the Sundarbans)

\begin{tabular}{|c|c|c|c|}
\hline \multirow{2}{*}{ Local Name } & \multirow{2}{*}{ Scientific Name } & \multicolumn{2}{|l|}{ Status } \\
\hline & & Outside the project area & Project area \\
\hline Akanda & Calotropis procera $\mathrm{Br}$. & $\mathrm{R}$ & Et \\
\hline Anantamul & Hemidesmus indicus L. & $\mathrm{R}$ & Et \\
\hline Apang/Shisakanda & Achyranthes aspera $L$. & $\mathrm{C}$ & $\mathrm{R}$ \\
\hline Bandhonia/Chinigura. & Scoparia dulcis $L$. & $\mathrm{C}$ & $\mathrm{F}$ \\
\hline Basak & Adhatoda vasica Nees. & $\mathrm{R}$ & $\mathrm{R}$ \\
\hline Chui Jhal & Piper chaba Hunter & $\mathrm{F}$ & $\mathrm{R}$ \\
\hline Dhutura & Datura metel Linn. & $\mathrm{F}$ & $\mathrm{R}$ \\
\hline Durba ghas & Cynodon dactylon Pers & $\mathrm{C}$ & $\mathrm{C}$ \\
\hline Ghritakumari & Aloe indica Willd. & $\mathrm{R}$ & $\mathrm{R}$ \\
\hline Hatisur & Heliotropium indicum L. & $\mathrm{C}$ & $\mathrm{F}$ \\
\hline Kalokasunda. & Cassia occidentalis L. & $\mathrm{C}$ & $\mathrm{R}$ \\
\hline Kalokeshi & Eclipta alba (Hassk). & $\mathrm{F}$ & $\mathrm{R}$ \\
\hline Kalomegh & Andrographis paniculata & $\mathrm{R}$ & Et \\
\hline Kumarilata. & Smilax zeylanica $L$. & $\mathrm{F}$ & $\mathrm{R}$ \\
\hline Lajjabati (white) & Mimosa pudica Linn. & $\mathrm{R}$ & Et \\
\hline Mehedi. & Lawsonia inermis L. & $\mathrm{F}$ & $\mathrm{R}$ \\
\hline Nayantara. & Catharanthus roseus. & $\mathrm{F}$ & $\mathrm{F}$ \\
\hline Nisinda & Vitex negundo L. & $\mathrm{F}$ & $\mathrm{R}$ \\
\hline Olotkombol & Abroma augusta $L$. & $\mathrm{F}$ & $\mathrm{R}$ \\
\hline Pathor kuchi & Kalanchoe pinnata (Lam.) & $\mathrm{C}$ & $\mathrm{F}$ \\
\hline Pipul & Piper longum Linn. & $\mathrm{R}$ & Et \\
\hline Pudina & Mentha arvensis $L$. & $\mathrm{F}$ & $\mathrm{R}$ \\
\hline Sharpagandha. & Rauwolfia serpentina & $\mathrm{R}$ & Et \\
\hline Shoti & Curcuma zedoaria Rosc. & $\mathrm{R}$ & Et \\
\hline Shotomuli & Asparagus racemosus $L$. & $\mathrm{R}$ & Et \\
\hline Telakucha & Coccina cordifolia (L) & $\mathrm{C}$ & $\mathrm{R}$ \\
\hline Thankuni & Centella asiatica (L) Urban. & $\mathrm{C}$ & $\mathrm{R}$ \\
\hline Tulshi & Ocimum basilicum Linn. & $\mathrm{C}$ & $\mathrm{F}$ \\
\hline \multicolumn{4}{|l|}{ Non-fruit trees } \\
\hline Arjun & Terminalia arjuna & $\mathrm{R}$ & $\mathrm{F}$ \\
\hline Asawatha & Ficus religiosa & $\mathrm{R}$ & $\mathrm{R}$ \\
\hline Bansh & Bambusa spp. & $\mathrm{C}$ & $\mathrm{R}$ \\
\hline Bot & Ficus benghalensis & $\mathrm{R}$ & $\mathrm{R}$ \\
\hline Jilapi & Acacia sp. & $\mathrm{F}$ & $\mathrm{R}$ \\
\hline Krishnachura & Delonix regia & $\mathrm{R}$ & $\mathrm{F}$ \\
\hline Mandar & Erythrina variegata & $\mathrm{F}$ & $\mathrm{R}$ \\
\hline Zigha & Lannea coromandelica & $\mathrm{C}$ & $\mathrm{R}$ \\
\hline
\end{tabular}

Status:VC, very common; C, common; F, fairly common; R, rare; E, endangered; T, threatened; Et, extinct (Source: Field study 20I I-20I3). 
Table I 0 Social forest plants and aquatic plants of the study area (except the Sundarbans)

\begin{tabular}{|c|c|c|c|}
\hline \multirow[t]{2}{*}{ Local Name } & \multirow[t]{2}{*}{ Scientific Name } & \multicolumn{2}{|l|}{ Status } \\
\hline & & \multirow[t]{2}{*}{ Outside the project area } & \multirow[t]{2}{*}{ Project area } \\
\hline \multicolumn{2}{|c|}{ Social forest plants } & & \\
\hline Akashmoni & Acacia moniliformis & $\mathrm{F}$ & $\mathrm{F}$ \\
\hline Rendi koroi & Samanea saman & $\mathrm{C}$ & $\mathrm{C}$ \\
\hline Shil koroi & Albizia sp. & $\mathrm{F}$ & $\mathrm{R}$ \\
\hline Mahogany & Swietenia mahagoni & $\mathrm{C}$ & $\mathrm{C}$ \\
\hline Piya & Melia sempervirens & $\mathrm{F}$ & $\mathrm{R}$ \\
\hline Eucalyptus & Eucalyptus citriodora & $\mathrm{F}$ & $\mathrm{F}$ \\
\hline Shegun & Tectona grandis & $\mathrm{R}$ & $\mathrm{R}$ \\
\hline Shishu & Dalbergia shishu & $\mathrm{C}$ & $\mathrm{C}$ \\
\hline Babla & Acacia arabica & $\mathrm{C}$ & $\mathrm{F}$ \\
\hline Ipil ipil & Leucaena latisiliqua & $\mathrm{C}$ & $\mathrm{F}$ \\
\hline \multicolumn{4}{|l|}{ Aquatic plants } \\
\hline Azola & Azolla pinnata & $\mathrm{R}$ & $\mathrm{R}$ \\
\hline Buripana & Spirodela polyrhiza & $\mathrm{C}$ & $\mathrm{C}$ \\
\hline Chaicha & Scirpus articulatus & $\mathrm{C}$ & $\mathrm{C}$ \\
\hline Dhol kalmi & Ipomoea fistulosa & $\mathrm{F}$ & $\mathrm{F}$ \\
\hline Helencha & Alternanthera philoxeroides & $\mathrm{C}$ & $\mathrm{F}$ \\
\hline Jhanji & Utricularia aurea & $\mathrm{R}$ & $\mathrm{R}$ \\
\hline Kachuri pana & Eichhornia crassipes & $\mathrm{C}$ & $\mathrm{F}$ \\
\hline Kalmi & Ipomoea aquatica & $\mathrm{F}$ & $\mathrm{R}$ \\
\hline Keshordam & Ludwigia adscendens & $\mathrm{C}$ & $\mathrm{F}$ \\
\hline Khudipana & Lemna minor & $\mathrm{C}$ & $\mathrm{C}$ \\
\hline Malanchi & Enhydra fluctuans & $\mathrm{F}$ & $\mathrm{R}$ \\
\hline Shapla & Nymphaea stellata & $\mathrm{F}$ & $\mathrm{R}$ \\
\hline Shusni shak & Marsilea quadrifolia & $\mathrm{C}$ & $\mathrm{F}$ \\
\hline Topapana & Pistia stratiotes & $\mathrm{F}$ & $\mathrm{R}$ \\
\hline
\end{tabular}

Status:VC, very common; C, common; F, fairly common; R, rare; E, endangered; T, threatened; Et, extinct (Source: Field study 20II-20I3).

Table I I Shrimp, crab, molluscs and fishes of the study areas (except the Sundarbans)

\begin{tabular}{|c|c|c|c|c|}
\hline Bangla Name & Scientific name & \multirow{2}{*}{ Habitat } & \multicolumn{2}{|l|}{ Status } \\
\hline Shrimp, crab and & usks & & Outside the project area & Project area \\
\hline Golda- chingri & Macrobrachium rosenbergii & $\mathrm{RB}$ & $\mathrm{C}$ & $\mathrm{R}$ \\
\hline Bagda- chingri & Penaeus monodon & $\mathrm{RB}$ & $\mathrm{C}$ & $\mathrm{R}$ \\
\hline Harina-chingri & Metapenaeus monoceros & $\mathrm{RB}$ & $\mathrm{C}$ & $\mathrm{R}$ \\
\hline Guara-chingri & Palaemon spp. & $\mathrm{RBP}$ & $\mathrm{C}$ & $\mathrm{F}$ \\
\hline Boro- kakara & Scylla serrata & $\mathrm{RBP}$ & $\mathrm{F}$ & $\mathrm{R}$ \\
\hline Choto-kakra & Gelasimus annulipes & RBP & $\mathrm{C}$ & $\mathrm{F}$ \\
\hline Boro- shamuk & Pila globosa & $\mathrm{BP}$ & $\mathrm{F}$ & $\mathrm{R}$ \\
\hline Guli- shamuk & Vivipara bengalensis & $\mathrm{BP}$ & $\mathrm{C}$ & $\mathrm{F}$ \\
\hline Choto- shamuk & Lymnaea spp. & $\mathrm{BP}$ & $\mathrm{C}$ & $\mathrm{F}$ \\
\hline Choto- shamuk & Bithynia tentaculata & RBP & $\mathrm{C}$ & $\mathrm{F}$ \\
\hline Lamba- shamuk & Melania tuberculata & $\mathrm{RB}$ & $\mathrm{F}$ & $\mathrm{R}$ \\
\hline Zinuk & Lamellideus marginalis & RBP & $\mathrm{F}$ & $\mathrm{R}$ \\
\hline
\end{tabular}


Table Continued

\begin{tabular}{|c|c|c|c|c|}
\hline Bangla Name & Scientific name & Habitat & Status & \\
\hline \multicolumn{5}{|l|}{ Fishes } \\
\hline Kakila & Xenentodon cancila & RBP & $\mathrm{C}$ & $\mathrm{R}$ \\
\hline Shol & Channa striatus & $\mathrm{RB}$ & $\mathrm{C}$ & $\mathrm{R}$ \\
\hline Taki & Channa punctatus & $\mathrm{RB}$ & $\mathrm{C}$ & $\mathrm{F}$ \\
\hline Gazar & Channa marulius & $\mathrm{RB}$ & $\mathrm{R}$ & $\mathrm{Et}$ \\
\hline Darkina & Esomus danricus & $\mathrm{RB}$ & $\mathrm{C}$ & $\mathrm{F}$ \\
\hline Chela & Onygaster phulo & $\mathrm{RB}$ & $\mathrm{F}$ & $\mathrm{Et}$ \\
\hline Mola & Amblypharyngodon mola & $\mathrm{RB}$ & $\mathrm{F}$ & $\mathrm{R}$ \\
\hline Rui & Labeo rohita & RBP & $\mathrm{C}$ & $\mathrm{C}$ \\
\hline Catla & Catla catla & RBP & $\mathrm{C}$ & $\mathrm{C}$ \\
\hline Mrigal & Cirrhinus mrigala & RBP & $\mathrm{C}$ & $\mathrm{C}$ \\
\hline Tatkini & Cirrhinus reba & $\mathrm{RB}$ & $\mathrm{F}$ & Et \\
\hline Silver carp & Hypophthalmichthys molitrix & RBP & $\mathrm{C}$ & $\mathrm{C}$ \\
\hline Grass carp & Ctenopharyngodon idella & RBP & $\mathrm{F}$ & $\mathrm{F}$ \\
\hline Carpio & Cyprinus carpio & RBP & $\mathrm{E}$ & Et \\
\hline Tit punti & Puntius ticto & RBP & $\mathrm{F}$ & $\mathrm{R}$ \\
\hline Punti & Puntius stigma & $\mathrm{RB}$ & $\mathrm{C}$ & $\mathrm{F}$ \\
\hline Thai punti & Puntius gonionotus & $\mathrm{RBP}$ & $\mathrm{F}$ & $\mathrm{F}$ \\
\hline Gutum & Lepidocephalus guntea & $\mathrm{RB}$ & $\mathrm{F}$ & $\mathrm{R}$ \\
\hline Shingi & Heteropneustes fossilis & $\mathrm{RB}$ & $\mathrm{C}$ & $\mathrm{F}$ \\
\hline Magur & Clarias batrachus & $\mathrm{RB}$ & $\mathrm{R}$ & Et \\
\hline Boal & Wallago attu & $\mathrm{RB}$ & $\mathrm{C}$ & Et \\
\hline Kani pabda & Ompok bimaculatus & $\mathrm{RB}$ & $\mathrm{R}$ & Et \\
\hline Pangas & Pangasius pangasius & RBP & $\mathrm{C}$ & $\mathrm{C}$ \\
\hline Rita & Rita rita & $\mathrm{RB}$ & $\mathrm{F}$ & Et \\
\hline Ayre & Mystus aor & $\mathrm{RB}$ & $\mathrm{C}$ & $\mathrm{Et}$ \\
\hline Tengra & Mystus vittatus & $\mathrm{RB}$ & $\mathrm{C}$ & $\mathrm{F}$ \\
\hline Chitol & Notopterus chitala & $\mathrm{RB}$ & $\mathrm{R}$ & Et \\
\hline Foli & Notopterus notopterus & $\mathrm{RB}$ & $\mathrm{F}$ & $\mathrm{Et}$ \\
\hline Chapila & Gudusia chapra & $\mathrm{RB}$ & $\mathrm{C}$ & $\mathrm{Et}$ \\
\hline Baim & Mastacembelus armatus & $\mathrm{RB}$ & $\mathrm{C}$ & Et \\
\hline Gochi baim & Mastacembelus pancalus & $\mathrm{RB}$ & $\mathrm{C}$ & $\mathrm{F}$ \\
\hline Tara baim & Macrognathus aculeatus & $\mathrm{RB}$ & $\mathrm{R}$ & $\mathrm{Et}$ \\
\hline Khalisha & Colisa fasciatus & $\mathrm{RB}$ & $\mathrm{C}$ & $\mathrm{F}$ \\
\hline Chata/Boichn & Colisa lalius & $\mathrm{RB}$ & $\mathrm{F}$ & $\mathrm{R}$ \\
\hline Koi & Anabas testudineus & $\mathrm{RB}$ & $\mathrm{F}$ & $\mathrm{R}$ \\
\hline Telapia & Oreochromis niloticus & RBP & $\mathrm{C}$ & $\mathrm{C}$ \\
\hline Baila & Glossogobius giuris & $\mathrm{RB}$ & $\mathrm{C}$ & $\mathrm{R}$ \\
\hline Baro chanda & Chanda nama & $\mathrm{RB}$ & $\mathrm{R}$ & $\mathrm{R}$ \\
\hline Choto chanda & Chanda ranga & $\mathrm{RB}$ & $\mathrm{F}$ & $\mathrm{R}$ \\
\hline Khorshula & Rhinomugil corsula & $\mathrm{RB}$ & $\mathrm{F}$ & $\mathrm{Et}$ \\
\hline Vetki & Lates calcarifer & $\mathrm{RB}$ & $\mathrm{C}$ & $\mathrm{F}$ \\
\hline Parshe & Liza spp. & $\mathrm{RB}$ & $\mathrm{C}$ & $\mathrm{F}$ \\
\hline Datina & Pomadasys hasta & $\mathrm{RB}$ & $\mathrm{C}$ & $\mathrm{F}$ \\
\hline Roop chanda & Pampus chinensis & $\mathrm{R}$ & $\mathrm{F}$ & $\mathrm{Et}$ \\
\hline Taposhi & Polynemus paradiseus & $\mathrm{R}$ & $\mathrm{F}$ & $\mathrm{Et}$ \\
\hline Khorkuno & Mugil spp. & RBP & $\mathrm{C}$ & $\mathrm{F}$ \\
\hline Ilish & Hilsa ilisha & $\mathrm{R}$ & $\mathrm{F}$ & Et \\
\hline
\end{tabular}

Habitat: R, River; B, Beel/Gher and P, Pond; Status:Vc,Very Common; C, Common; F, Fairly Common; R, Rare and T, Threatened; Et, Extinct (Source: Field study 20II-20I3). 
Table I 2: Amphibians and reptiles of the study areas (except the Sundarbans).

\begin{tabular}{|c|c|c|c|c|}
\hline & & & \multicolumn{2}{|l|}{ Status } \\
\hline Amphibians & & & $\begin{array}{l}\text { Outside of } \\
\text { the project } \\
\text { area }\end{array}$ & $\begin{array}{l}\text { Project } \\
\text { area }\end{array}$ \\
\hline Kotkoti/Baiya bang & Skipper frog & Rana cyanophlyctis & $\mathrm{F}$ & $\mathrm{R}$ \\
\hline Sonalibang & Bull frog & Rana tigrina & $\mathrm{F}$ & $\mathrm{R}$ \\
\hline Kunobang & Toad & Bufo melanostictus & $\mathrm{F}$ & $\mathrm{F}$ \\
\hline Reptiles & & & & \\
\hline Tiktiki & Wall lizard & Hemidactylus flaviviridis & C & C \\
\hline Anjali/Nenja & Shink & Mabuya carinata & C & $\mathrm{F}$ \\
\hline Kalo Gui shap & Monitor lizard/Grey lizard & Varanus bengalensis & C & $\mathrm{F}$ \\
\hline Sonali/Haldey Gui & Yellow lajnd monitor & Varanus flavescens & $\mathrm{F}$ & $\mathrm{R}$ \\
\hline Bara-kasim & Soft shell turtle & Trionyx gangeticus & $\mathrm{R}$ & Et \\
\hline Kaitta /Kori kaitta & Roofed turtle & Kachuga tecta & $\mathrm{F}$ & $\mathrm{R}$ \\
\hline Saundi kasim & Spotted flap shell tortoise & Lissemys punctata & $\mathrm{F}$ & Et \\
\hline Paina/Matia shap & Common water snake & Enhydris enhydris & C & $\mathrm{F}$ \\
\hline Dora Shap & Checkered keelback & Xenochrophis piscator & C & $\mathrm{F}$ \\
\hline Daras shap & Rat snake & Ptyas mucosus & $\mathrm{F}$ & $\mathrm{R}$ \\
\hline Gokhra shap & Cobra & Naja naja & $\mathrm{F}$ & $\mathrm{R}$ \\
\hline
\end{tabular}


Table 13 Birds of the study areas (except the Sundarbans)

\begin{tabular}{|c|c|c|c|c|}
\hline Bangla name & English name & Scientific name & Status & \\
\hline Amphibians & & & Outside of the project area & Project area \\
\hline Kotkoti/Baiya bang & Skipper frog & Rana cyanophlyctis & $\mathrm{F}$ & $\mathrm{R}$ \\
\hline Sonalibang & Bull frog & Rana tigrina & $\mathrm{F}$ & $\mathrm{R}$ \\
\hline Kunobang & Toad & Bufo melanostictus & $\mathrm{F}$ & $\mathrm{F}$ \\
\hline \multicolumn{5}{|l|}{ Reptiles } \\
\hline Tiktiki & Wall lizard & Hemidactylus flaviviridis & $\mathrm{C}$ & $\mathrm{C}$ \\
\hline Anjali/Nenja & Shink & Mabuya carinata & $\mathrm{C}$ & $\mathrm{F}$ \\
\hline Kalo Gui shap & Monitor lizard/Grey lizard & Varanus bengalensis & $\mathrm{C}$ & $\mathrm{F}$ \\
\hline Sonali/Haldey Gui & Yellow lajnd monitor & Varanus flavescens & $\mathrm{F}$ & $\mathrm{R}$ \\
\hline Bara-kasim & Soft shell turtle & Trionyx gangeticus & $\mathrm{R}$ & Et \\
\hline Kaitta /Kori kaitta & Roofed turtle & Kachuga tecta & $\mathrm{F}$ & $\mathrm{R}$ \\
\hline Saundi kasim & Spotted flap shell tortoise & Lissemys punctata & $\mathrm{F}$ & Et \\
\hline Paina/Matia shap & Common water snake & Enhydris enhydris & $\mathrm{C}$ & $\mathrm{F}$ \\
\hline Dora Shap & Checkered keelback & Xenochrophis piscator & $\mathrm{C}$ & $\mathrm{F}$ \\
\hline Daras shap & Rat snake & Ptyas mucosus & $\mathrm{F}$ & $\mathrm{R}$ \\
\hline Gokhra shap & Cobra & Naja naja & $\mathrm{F}$ & $\mathrm{R}$ \\
\hline Bhuban cheel & Black kite & Milvus migrans & $\mathrm{F}$ & $\mathrm{F}$ \\
\hline Tila baz & Kestre eagle & Falco tinnunculus & $\mathrm{R}$ & Et \\
\hline Mala ghughu & Ring dove & Streptopelia decaocto & $\mathrm{F}$ & $\mathrm{R}$ \\
\hline Tila ghughu & Spotted dove & Streptopelia chinensis & $\mathrm{F}$ & $\mathrm{R}$ \\
\hline Jalali cobutor & Blue R. pigeon & Columba livia & $\mathrm{C}$ & $\mathrm{C}$ \\
\hline Teya & Parakeet & Psittacula krameri & $\mathrm{F}$ & $\mathrm{R}$ \\
\hline Kokil & Koel & Eudynamys scolopacea & $\mathrm{F}$ & $\mathrm{F}$ \\
\hline Kanakoka & Lesser coucal & Centropus bengalensis & $\mathrm{F}$ & Et \\
\hline Lokhi pecha & Bran owl & Tyto alba & $\mathrm{F}$ & $\mathrm{R}$ \\
\hline Bhutum pecha & Spotted owlet & Athene brama & $\mathrm{F}$ & $\mathrm{R}$ \\
\hline Katthokra & Golden-backed wood pecker & Dinopium javanense & $\mathrm{F}$ & $\mathrm{R}$ \\
\hline Ababil & House swift & Apus affinis & $\mathrm{C}$ & $\mathrm{C}$ \\
\hline Shipahi-bulbul & Red-whiskerdbulbul & Pycnonotus cafer & $\mathrm{C}$ & $\mathrm{C}$ \\
\hline Doyal & Magpic robin & Copsychus saularis & $\mathrm{C}$ & $\mathrm{C}$ \\
\hline Tuntune & Tailor bird & Orthotomus sutorius & $\mathrm{F}$ & $\mathrm{F}$ \\
\hline Fingae & Black drongo & Dicrurus macrocercus & $\mathrm{C}$ & $\mathrm{C}$ \\
\hline Pati kak & House crow & Corvus splendens & $\mathrm{C}$ & $\mathrm{C}$ \\
\hline Dar kak & Jungle corw & Corvus macrorhynchos & $\mathrm{C}$ & $\mathrm{C}$ \\
\hline Baht salik & Common myna & Acridotheres tristis & $\mathrm{C}$ & $\mathrm{C}$ \\
\hline Jhuti-salik & Pied myna & Sturnus contra & $\mathrm{C}$ & $\mathrm{C}$ \\
\hline Chorui & House sparrow & Passer domestica & $\mathrm{C}$ & $\mathrm{C}$ \\
\hline Babui & Baya & Ploceus philippinus & $\mathrm{C}$ & $\mathrm{F}$ \\
\hline Kutum & Black headed oriole & Oriolus chinensis & $\mathrm{F}$ & $\mathrm{R}$ \\
\hline Shakun & White backed vulture & Gyps bengalensis & $\mathrm{R}$ & Et \\
\hline \multicolumn{5}{|l|}{ Wetlands bird } \\
\hline Pancowri & Little cormorant & Phalacrocorax niger & $\mathrm{F}$ & Et \\
\hline Kani bok & Pond heron & Ardeola grayii & $\mathrm{C}$ & $\mathrm{F}$ \\
\hline Sada bok & Little egret & Egretta garzetta & $\mathrm{C}$ & $\mathrm{F}$ \\
\hline Bali hash & Lesser Whistling duck & Dendrocygna javanica & $\mathrm{F}$ & Et \\
\hline Chota machranga & Common kingfisher & Alcedo atthis & $\mathrm{F}$ & $\mathrm{R}$ \\
\hline Machranga & White throated kingfisher & Halcyon smyrnensis & $\mathrm{C}$ & $\mathrm{R}$ \\
\hline Dahuk & Water hen & Gallicrex cinerea & $\mathrm{F}$ & Et \\
\hline Kora & Water cock & Amaurornis phoenicurus & $\mathrm{F}$ & Et \\
\hline Shamuk banga & Openbill stork & Anastomus oscitans & $\mathrm{T}$ & Et \\
\hline Pancowri & Little cormorant & Phalacrocorax niger & $\mathrm{F}$ & Et \\
\hline
\end{tabular}

Status:VC,Very Common; C, Common; F, Fairly Common; R, Rare and T,Threatened; Et, Extinct; (Source: Field study 20I I-20I3). 
Table I 4 List of mammals the project area (except the Sundarbans)

\begin{tabular}{lllll}
\hline Bangla name & English name & Scientific name & Status & Project area \\
\cline { 3 - 4 } Borobadur & Flying fox & Pteropus giganteus & $\mathrm{F}$ & $\mathrm{R}$ \\
Shial & Jackal & Canis aureus indicus & $\mathrm{R}$ & $\mathrm{Et}$ \\
Khak shial & Fox & Vulpes bengalensis & $\mathrm{T}$ & $\mathrm{Et}$ \\
Beji & Mongoose & Herpestes edwardsii & $\mathrm{T}$ & $\mathrm{R}$ \\
Banbiral/Bona & Jungle cat & Felis chaus & $\mathrm{T}$ & $\mathrm{Et}$ \\
Khorgosh & Black-naped hare & Lepus nigricollis & $\mathrm{Et}$ & $\mathrm{Et}$ \\
Katbirali & Irrawadedy squirre & Callosciurus pygeregthrus & $\mathrm{R}$ & $\mathrm{Et}$ \\
Udd & Otter & Lutra lutra & $\mathrm{T}$ & $\mathrm{Et}$ \\
Gaso indur & L.bandicoot rat & Bandicota bengalensis & $\mathrm{C}$ & $\mathrm{F}$ \\
Indur & G.bandicoot rat & Bandicota indica & $\mathrm{Cc}$ & $\mathrm{C}$ \\
Chika/Sucho & House shrew & Suncus murinus & $\mathrm{C}$ &
\end{tabular}

Status:VC,Very Common; C, Common; F, Fairly Common; R, Rare and T,Threatened; Et, Extinct; (Source: Field study 20I I-20I3).

\section{Acknowledgements}

None.

\section{Conflict of interest}

The author declares no conflict of interest.

\section{References}

I. Mittal ML, C Sharma, R Singh. Estimates of emissions from coal fired thermal power plants in India. Radio and atmospheric Sciences Div Nat Phy Lab, Council of sci and ind Res New Delhi- I I00I2 India; 20I I. 22 p.

2. Environmental impacts of coal power: wastes generated. Union of concerned scientists, National Headquarters. 2 Brattle Square, Cambridge, USA: UCS; 2012.

3. ADB. Environmental assessment guidelines. Asian development bank; 2003. $175 \mathrm{p}$.

4. Billings P. Emissions of hazardous air pollutants from coal-fired power plant. Needham MA: Environmental health and engineering, Inc; 201 I. 46 p.

5. Sattar MA. Saving Sundarban for millions of years as world heritage. Bangladesh J Environ Sci. 2010; 19:13-24.

6. Sarkar PK. Fighting for the survival of the Sundarbans. Bangladesh:The Daily Star; 2012.

7. Hossain GM. Ecosystem health status assessment of the Sundarbans mangrove forest in Bangladesh. Dhaka; Jahangirnagar University: 2014.

8. The Bangladesh Sundarbans:A Photoreal Sojourn. IUCN Bangladesh country office Dhaka, Bangladesh: IUCN; 200I. I 86 p.

9. Chowdhury AH. Glimpses of flora and fauna of the Sundarbans. Proceedings of the National seminar on the Sundarbans, the largest mangrove forest on the earth:A World Heritage Site, Bangladesh: Khulna University; 2003.

10. Biswas SR, Choudhury JK, Nishat A, et al. Do invasive plants threaten the Sundarbans mangrove forest of Bangladesh? Forest Ecology and Management. 2007;245(I-3): I-9.

II. Uddin MS, E de R van Steveninck, Stuip M, Shah MAR. Economic valuation of provisioning and cultural services of a protected mangrove ecosystem: a case study on sundarbans reserve forest, Bangladesh. Ecosystem Services.

\section{3;5:88-93.}

12. Sattar MA. Impact of coal-fired power plant on air pollution, climate changes and environmental degradation. Bangladesh J Environ Sci. 2010;19:1-I2.

13. DoE. Fourth National Report to the Convention on Biological Diversity Biodiversity. Government of the People's Republic of Bangladesh; 2010.

14. Trivedy RK. River pollution in India. House, New Delhi, India: Ashish Publ; 1993. 294 p.

15. Gautam A. Ecology and pollution of mountain water. House, New Delhi, India: Ashish Publ; 1990. 209 p.

16. Jackson ML. Soil chemical analysis. New Delhi, India: Prentice-Hall of India Pvt. Ltd; 1973.

17. Page AL, RH Miller, DR Keeney. Methods of soil analysis (Part-2) American society of agronomy. Madison, Wisconsin, USA: 1982.

18. Jayaraman K, PS Easa, EA Jayson. Evaluation of methods for estimating the abundance of herbivores in the forests of Kerala. Peechi, Thrissur India; Kerala Forest Research Institute; 1998. 47 p.

19. Hoshmand AR. Statistical methods for environmental and agricultural sciences. New York, USA: CRR Press LLC; 1998. 439 p.

20. Chowdhury AH. Environmental impact of salinity increasing on soil, water and floral diversity of Rampal upazila, Bagerhat. UGC Funded Research Report, Env Sci Discipline Khulna Univ Bangladesh; 20I2. 16 p.

21. Ahmed R, Rahman MM, Chowdhury AH. Physico-chemical attributes of different water bodies of Rampal Upazila at Bagerhat. Bangladesh Jahangirnagar University J Biol Sci. 201 3; I (2):27-32.

22. Rahman MM, Rahman MT, Rahman MS, et al. Water quality of the world's largest mangrove forest. Canadian Chem. Transactions. 20I3; I (2): I4 I-I 56.

23. Chowdhury $\mathrm{AH}$. Environmental threats on the plant resources of the sundarbans-the world heritage site of Bangladesh (ICAER/O//O3). Proceedings of international conference on advances in ecological research (19-2I December, 20 I I) M Ganga Singh University; Bikaner 334 00I India; 20 I I.

24. Mannan MA. Impact of environmental hazards on the plant diversity of the Sundarbans Satkhira range. Ph.D. Thesis (unpubl.) Dhaka, Bangladesh: Dept Bot Jahangirnagar University; 2010 pp. 157.

25. Hussain Z, Acharya G. Mangrove of the Sundarbans. Volume 2: Bangladesh, 
Bangkok, Thailand: IUCN; 1994. 180 p.

26. Chowdhury AH,Akber MA. Study of Impacts of oil spill on the Sundarbans mangrove forest of Bangladesh. J Asiat Soci Bangladesh Sci. 20I5;4I(I):7594.

27. Pastakia CMR, Jensen A. The rapid impact assessment matrix (RIAM) for EIA. Environ Impact Asses Rev. 1998; 18:461-482.

28. Ambasht RS. Plant Ecology. Varanasi India: Students' Friends and Co; 1974. $261 \mathrm{p}$.

29. APHA. Standard methods for the examination of water and waste water. Washington:American Public Health Association; 1989. 1125 p.

30. Welch PS. Limnological Methods. New York: Mc Graw Hill Book Company; 1948. 38I p.

31. Final Report on environmental impact assessment of $2 x$ (500-660) MW coal based thermal power plant to be constructed at the location of Khulna. Ministry ofWater Resources, Bangladesh: Center for environmental and geographic information services; 2013.500 p.

32. EIA Guidelines for Industries by department of environment. Ministry of environment and forest, Government of the People's Republic of Bangladesh: DoE; 1997.

33. Guidelines for Environmental impact assessment (EIA). Ministry of water resources, Government of the People's republic of Bangladesh: Flood Plan Coordination Organization; 1992.

34. Giri C, Pengra B, Zhu Z, et al. Monitoring Mangrove Forest Dynamics of the Sundarbans in Bangladesh and India Using Multi-Temporal Satellite Data from 1973 to 2000. Estuarine, Coastal and Shelf Science. 2007;73(I 2):91-100.

35. Jahan MS, GMJ Islam, MR Rahman. Molluscan biodiversity of Sundarbans, Bangladesh. Proceeding of the National Seminar on coastal environment and energy resources in Bangladesh, organized by environmental Sci. Discipline, Bangladesh: Khulna University; 2000. p. 8-9.

36. Ministry of environment and forests. Technical EIA guidance manual for thermal power plants. Government of India: IL\&FS Ecosmart Ltd; 20I0. 269 p.

37. Mishra SN, R Swarup, VP Jauhari. Encyclopaedia of ecology, Environment and pollution control. Environmental air and water analysis. House, New Delhi India:Ashish Publ; 1992. 17 p.

38. Rahman F, Rahman MT, Rahman MS, et al. Organic production of Koromjol, Passur river system of the sundarbans, Bangladesh. Asian J of Water Env and Pollution. 20I4; I I (I):95-103. 